https://doi.org/10.17816/MAJ191S1201-202

\title{
THE EFFECT OF AFOBAZOL ON THE NEUROAMINE STATUS OF THE THYMUS OF WHITE RATS
}

\author{
N.E. Gimaldinova, L.A. Lyubovtseva, E.A. Guryanova, O.V. Vorobeva \\ Chuvash State University named after I.N. Ulyanov, Cheboksary, Russia
}

\section{ВЛИЯНИЕ АФОБАЗОЛА НА НЕЙРОАМИННЫЙ СТАТУС ТИМУСА БЕЛЫХ КРЫС}

\author{
Н.Е. Гималдинова, Л.А. Любовцева, Е.А. Гурьянова, О.В. Воробьева
}

ФГБОУ ВО «Чувашский государственный университет им. И.Н. Ульянова», Чебоксары

\begin{abstract}
Often used in medical practice drug Afobazol has a wide range of actions. The paper describes the morphological changes of neuroamine-containing structures of the thymus of white rats with long-term (8 weeks) afobazole administration. By fluorescent histochemistry was determined by the content of catecholamines, histamine, and serotonin in the structures of the thymus. Under the influence of afobazole, the luminescent picture in the structures of the thymus changes, the clear boundary between the cortical and medullary substance of the thymus lobe is erased. The introduction of Afobazole leads to a decrease in the concentration of biogenic amines in premedullary GLA and an increase in the concentration in the microenvironment, which indicates a decrease in the amino-producing properties of these cells and the release of neurotransmitters from GLA.
\end{abstract}

Keywords: granular luminescent cells (GLC); catecholamines (KA); serotonin (ST); histamine (G); thymus.

Часто применяемый в лечебной практике препарат афобазол обладает широким спектром действий. В работе описаны морфологические изменения нейроаминсодержащих структур тимуса белых крыс при длительном (8 недель) приеме афобазола. Методами люминесцентной гистохимии определяли содержание катехоламинов, гистамина, серотонина в структурах тимуса. Под воздействием афобазола люминесцентная картина в структурах тимуса изменяется, четкая граница между корковым и мозговым веществом тимусной дольки стирается. Введение Афобазола приводит к понижению концентрации биогенных аминов в премедуллярных ГЛК и увеличению концентрации в микроокружении, что указывает на снижение аминопродуцирующих свойств этих клеток и выброс нейромедиаторов из ГЛК.

Ключевые слова: гранулярные люминесцирующие клетки (ГЛК); катехоламины (КА), серотонин (СТ); гистамин; тимус.

Introduction. The current practice of selling medicines without a prescription leads to the fact that the population begins to take the advertised drugs uncontrollably, often without thinking about the possible effects or side effects of the drug. Afobazole is a derivative of 2-mercaptobenzimidazole, a selective anxiolytic not belonging to the class of benzodiazepine receptor agonists. Prevents the development of membrane-dependent changes in the GABA receptor. It has an anxiolytic (antianxiety) effect and a mild stimulating (activating) effect [1]. One of the side effects of afobazole is an allergic reaction. However, no effects on the internal structure of immune organs, such as the thymus, are described in the literature. The aim of the work is to study the morphological and functional characteristics of the thymus and to identify the content of catecholamines, histamine and serotonin after course administration of afobazole.

Materials and methods. The study was conducted on 30 white male rats of the line "Wistar". Within eight days, the animals received afobazole at a dose of $0.5 \mathrm{mg} / \mathrm{kg}$ body weight for 8 weeks. Cryostat sections of fresh frozen bodies with a thickness of $15 \mu \mathrm{m}$ was processed: luminescent- histochemical method of Cross, with the Soave. (1971) for the detection of histamine; luminescent-histochemical method of Falk-Hillarp in the modification of Krokhino E.M., p. P. Alexandrova (1969) for the selective detection of SC and ST; spectrofluorimetry method was used for quantitative measurements of the concentration of ST, SC and histamine in the structures of the thymus. Quantitative distribution of cells was carried out by counting them in 5 fields of view of the microscope at 400 magnification.

Research result. Luminescent-histochemical study of the thymus showed that the main histamine-containing structures of the thymus are granular luminescent cells of the premedullary and subcapsular zones identified as macrophages and dendritic cells, mast cells (TC). Most of the granular cells of the premedullary zone play the role of amino producers, and macrophages of the subcapsular zone - amine absorbers [2]. Under the influence of afobazole the fluorescent pattern in the structures of the thymus is altered, a clear boundary between cortical and medullary substance of thymus lobules is obliterated, although in some places preserved "remnants" of the chain from 
The intensity of luminescence of catecholamines, serotonin, histamine in the structures of the thymus of white rats Wistar rats in norm and after administration of Afobazole

\begin{tabular}{|l|c|c|c|c|c|c|}
\hline \multirow{2}{*}{$\begin{array}{c}\text { The structure } \\
\text { of the thymus }\end{array}$} & \multicolumn{3}{|c|}{ Intact group } & \multicolumn{3}{c|}{ Experimental group } \\
\cline { 2 - 7 } & CA & ST & G & CA & ST & G \\
\hline GLC p/m & $44.0 \pm 2.5$ & $50.0 \pm 3.5$ & $15.2 \pm 1.9$ & $34 \pm 1.05$ & $39.6 \pm 1.86^{*}$ & $39.0 \pm 3.0^{*}$ \\
\hline GLC s/C & $37.6 \pm 2.44$ & $44 \pm 3.08$ & $14.8 \pm 5.41$ & $57.8 \pm 2.58$ & $73.8 \pm 2.82^{*}$ & $38.0 \pm 2.81^{*}$ \\
\hline CT & $26.75 \pm 2.2$ & $33.5 \pm 2.9$ & $6.25 \pm 0.95$ & $30.75 \pm 1.3$ & $38.0 \pm 1.08^{*}$ & $17.0 \pm 1.3^{*}$ \\
\hline MT & $19.75 \pm 2.25$ & $24.5 \pm 2.25$ & $9.5 \pm 2.47$ & $29.75 \pm 3.9$ & $35.5 \pm 1.9^{*}$ & $18.25 \pm 1.17^{*}$ \\
\hline TC & $30.2 \pm 1.2$ & $41.3 \pm 2.4$ & $18.1 \pm 1.9$ & $28.2 \pm 1.0$ & $40.3 \pm 2.1^{*}$ & $19.6 \pm 1.1^{*}$ \\
\hline
\end{tabular}

N o t e: ${ }^{*} p \geq 0.05$ characterizes the reliability in relation to the intact group of animals. GLC $\mathrm{p} / \mathrm{m}-$ granular luminescent cells of the premedular zone, GLC s/C - granular luminescent cells of the subcapsular zone, CT - cortical thymocytes, MT - brain thymocytes, TC - mast cells, CA - catecholamines, ST - serotonin, G - histamine.

one row premedullary macrophages. In the subcapsular zone the number of macrophages increases and reaches $15-30$ in one field of vision instead of $8-10$ in intact animals. The content of histamine in subcapsular thymocytes increased 2.1 times, in thymocytes of brain matter-decreased 1.35 times. According to Brostoff $\mathrm{G}$ in a large number of supressiruet an early stage of development of cells in the brain macrophages and thymocytes, its content decreases, leading to increased differentiation of cells, including lymphocytes. The content of serotonin (CT) increased in subcapsular thymocytes by 1.8 times, and in thymocytes of brain matter did not change significantly. Response in thymocytes in different directions: the cortical thymocytes respond more actively than the brain. The content of catecholamines (KA) increased in the thymocytes of the brain substance by 1.1 times, in the thymocytes of the subcapsular zone - by 1.68 times. The content of $\mathrm{G}$ decreased in premedullary macrophages by 2.47 times, in subcap- sular macrophages-by 2.41 times. The content of $\mathrm{KA}$ and $\mathrm{CT}$ in subcapsular macrophages in 1.2 and 1.3 times.

Thus, the introduction of Afobazole leads to a decrease in the concentration of biogenic amines in premedullary macrophages and an increase in the concentration in the microenvironment, which indicates a decrease in the amine-producing properties of these cells and the release of neurotransmitters, a similar pattern was observed with the introduction of immunomodulators [3].

Conclusion. Receiving afobazole increases the content of serotonin and catecholamines in the thymocytes of the medulla and the subcapsular zone of the thymus, and a reduction in granular luminescent cells premedullary and subcapsular areas of the thymus. An increase in the content of histamine was noted in subcapsular thymocytes, and significantly decreased in thymocytes of brain matter, in premedullary and subcapsular macrophages.

\section{References}

1. Yarkova MA. Anxiolytic properties of afobazol in comparison with diazepam. European Neuropsychopharmacology. 2005:S145.

2. Bugaeva LI, Denisova TD, Sergeeva SA, Kharlamov IV. The Study of prenatal development of fetuses of rats treated with afobazole during the period of organogenesis. Bulletin of experimental biology and medicine. 2014;7:S64-67.

3. Vorobeva OV. Dynamics of morpho-functional conditions of cellular programmed differentiation in bone marrow as a hemopoietic organ. Zhurnal anatomii i gistopatologii. 2017;6(2):26-29.

4. Vorobeva OV, Lyubovtseva LA, Gimaldinova NE. Enzymatic provision of bone marrow cells after transplantation. Journal of anatomy and histopathology. 2018;7(3):9-12.

5. Gimaldinova NE, Lyubovtseva LA, Plyukhin SV. Influence of cycloferon on the distribution of histamine in biomesotherapy structures of the thymus gland. In: Issues of medical rehabilitation. Collection of scientific works on the results of Interregional scientific-practical conference. Cheboksary; 2018. P. 113-116.

6. Gimaldinova NE, Ignatieva EN, Lyubovtseva LA, et al. The effects of cycloferon on the distribution of neuroamines in bioamine-containing structures of the spleen. Bulletin of new medical technologies. 2018;25(3):101-106.

7. Solenovata EA, Guryanova EA, Alekseeva LA. Analysis of the activity structures of the thymus and the early immune response in patients receiving immunomodulator. Bulletin of Chuvash University. 2013;(3):511-516. 